\title{
Exogenous Growth Hormone Inhibits Growth Hormone-releasing Factor-induced Growth Hormone Secretion in Normal Men
}

Stephen M. Rosenthal, J. Anthony Hulse, Selna L. Kaplan, and Melvin M. Grumbach

Department of Pediatrics, University of California at San Francisco, California 94143

\begin{abstract}
Previous studies from this laboratory and by others in rats, monkeys, and humans support the concept that growth hormone (GH) can regulate its own secretion through an autofeedback mechanism. With the availability of human growth hormone-releasing factor (GRF), the possible existence of such a mechanism was reexplored by examining the effect of exogenous GH on the GH response induced by GRF-44- $\mathrm{NH}_{2}$ in six normal men (mean age, $32.4 \mathrm{yr}$ ). In all subjects the plasma $\mathrm{GH}$ response evoked by GRF-44-NH $\mathrm{N}_{2}(1 \mu \mathrm{g} / \mathrm{kg}$ i.v. bolus) was studied before and after $5 \mathrm{~d}$ of placebo (1 $\mathrm{ml}$ normal saline $\mathrm{i} . \mathrm{m}$. every $12 \mathrm{~h}$ ), and then before and $12 \mathrm{~h}$ after $5 \mathrm{~d}$ of biosynthetic methionyl human GH (5 $\mathrm{U}$ i.m. every $12 \mathrm{~h}$ ). The GH response to GRF (maximal increment over time 0 value) was significantly inhibited after $\mathbf{G H}$ treatment (0-1.3 vs. $2.3-11.2 \mathrm{ng} / \mathrm{ml}$ before treatment, $P=0.05$ ), but was not significantly affected by placebo. This impaired pituitary response to GRF persisted for at least $24 \mathrm{~h}$ following exogenous GH treatment in two subjects who underwent further study. Serum somatomedin-C concentrations were significantly increased after $5 \mathrm{~d}$ of $\mathrm{GH}$ treatment (2.66-5.00 vs. 0.92-1.91 $\mathrm{U} / \mathrm{ml}$ before treatment, $P=<0.01$ ). The impaired pituitary response to GRF may be mediated indirectly through somatomedin, somatostatin, by a direct effect of GH on the pituitary somatotropes, or by all of these mechanisms. These data suggest that after GH treatment, the blunted GH response to synthetic GRF is not solely a consequence of the inhibition of hypothalamic GRF secretion.
\end{abstract}

\section{Introduction}

Previous studies from this laboratory and by others in rats, monkeys, and humans support the concept that growth hormone $(\mathrm{GH})^{1}$ can regulate its own secretion through an autofeedback mechanism (1-12). Such studies demonstrated that exogenous GH either led to diminished pituitary GH content (1-6), blunted the $\mathrm{GH}$ response to provocative stimuli $(7-10)$, or decreased

A preliminary report of this work was presenied at the 7th International Congress of Endocrinology, Quebec, Canada, July 1984 (abstract No. 1768).

Address reprint requests to Dr. Grumbach, Departinent of Pediatrics, University of California at San Francisco, CA 94143

Received for publication 5 November 1984 and in revised form 20 August 1985.

1. Abbreviations used in this paper: GH, growth hormone; SRIF, somatotropin-release inhibiting factor (somatostatin); GRF, GH-releasing factor; SM-C, somatomedin-C.

J. Clin. Invest.

(c) The American Society for Clinical Investigation, Inc.

0021-9738/86/01/0176/05 \$1.00

Volume 77, January 1986, 176-180 pulsatile GH secretion $(11,12)$. These reports preceded the isolation, characterization, and synthesis of somatostatin (13) and growth hormone-releasing factor (GRF) $(14,15)$, and antedated observations of the direct stimulatory effect of GH on somatotropin-release-inhibiting factor (SRIF) release (16-19), of the noncompetitive antagonism between SRIF and GRF at the level of the somatotrope $(20,21)$, and of the multiple negative feedback effects of somatomedin-C (SM-C) on GH secretion (22-24).

With the availability of GRF, we wished to investigate further the possible existence of a $\mathrm{GH}$ autofeedback mechanism in vivo by examining the effect of exogenous GH on the GRF-induced $\mathrm{GH}$ response in normal men. Our results demonstrate that $\mathrm{GH}$ secretion evoked by GRF-44- $\mathrm{NH}_{2}$ is inhibited after treatment with GH. This impaired pituitary response to GRF may be mediated indirectly through somatostatin, somatomedin, by a direct effect of GH itself, or by all of these mechanisms.

\section{Methods}

Subjects and experimental design. Studies were carried out in six normal men aged 26-35 yr (mean, $32.4 \mathrm{yr}$ ) in the General Clinical Research Center at the University of California at San Francisco. All subjects gave written, informed consent. The GH response evoked by GRF-44- $\mathrm{NH}_{2}$ $(1 \mu \mathrm{g} / \mathrm{kg}$ i.v. bolus) was studied in all subjects before and after $5 \mathrm{~d}$ of placebo $(1 \mathrm{ml}$ normal saline i.m. every $12 \mathrm{~h}$ ) and before and $12 \mathrm{~h}$ after $5 \mathrm{~d}$ of biosynthetic methionyl human GH ( $5 \mathrm{U}$ i.m. every $12 \mathrm{~h}$ ). Plasma samples for $\mathrm{GH}$ were obtained at $-60,-45,-30,-15,0,10,15,20$, $30,45,60,90,120$, and 180 min after each GRF bolus; serum samples for SM-C were obtained at time 0 and $24 \mathrm{~h}$ after GRF. In addition, samples were collected for $\mathrm{GH}$ and SM-C before each injection of placebo and GH. In two subjects the GRF-induced GH response was also examined $24 \mathrm{~h}$ after the completion of exogenous $\mathrm{GH}$ administration.

The placebo period always preceded the GH treatment period in order to eliminate the possibility that prior $\mathrm{GH}$ treatment might affect the response to GRF during the control studies. In addition, the placebo and GH treatment periods were always separated by a minimum of 1 wk. This study design provided an opportunity to observe the variability of the GRF-induced GH response in the same subject, as each subject received three identical bolus injections of GRF before the administration of $\mathrm{GH}$.

Materials and assays. GRF-44- $\mathrm{NH}_{2}$ was provided by Dr. Roger Guillemin and Dr. Nicholas Ling of the Salk Institute, La Jolla, CA. Biosynthetic methionyl human GH was contributed by Genentech, Inc., South San Francisco, CA.

GH was measured in plasma samples using a double-antibody radioimmunoassay procedure as previously described (25), with reference standard AFP 4793 . The assay sensitivity was $0.3 \mathrm{ng} / \mathrm{ml}$. The intrassay and interassay coefficients of variation were 3 and $6 \%$, respectively. Serum SM-C was determined by double-antibody radioimmunoassay procedure, following acid-ethanol extraction as previously described (26); the reference standard was synthetic SM-C (Li 4378B). The assay sensitivity was $0.1 \mathrm{U} / \mathrm{ml}$, and intraassay and interassay coefficients of variation were 8 and $15 \%$, respectively.

Statistical analysis. Plasma GH concentrations were expressed as nanograms per milliliter. The maximal increment over the time $0, G R F$ 
value was determined and responses were compared by the Friedman test (nonparametric analogue of repeated-measures analysis of variance) with subsequent pairwise study made with the Wilcoxon test. Serum SM-C concentrations were expressed as units per milliliter. These nonparametric data were also analyzed by the Friedman and Wilcoxon tests.

\section{Results}

The plasma GH responses evoked by GRF-44-NH $\mathrm{N}_{2}$, both before and after placebo and before and after GH treatment, are shown in Fig. 1. A striking variability in the $\mathrm{GH}$ response was noted before and after placebo as well as before $\mathrm{GH}$, but the variability was greatly diminished after GH treatment. This variability was observed not only between individuals, but within the same sub-

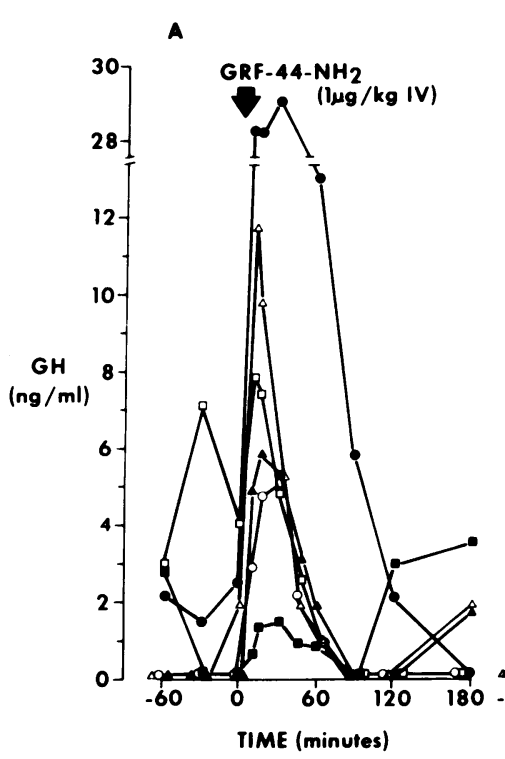

B

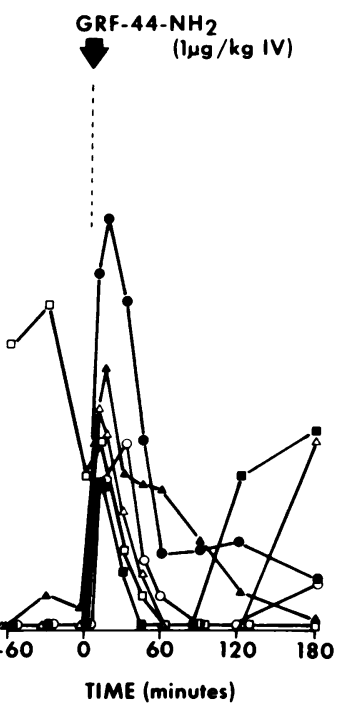

C

D

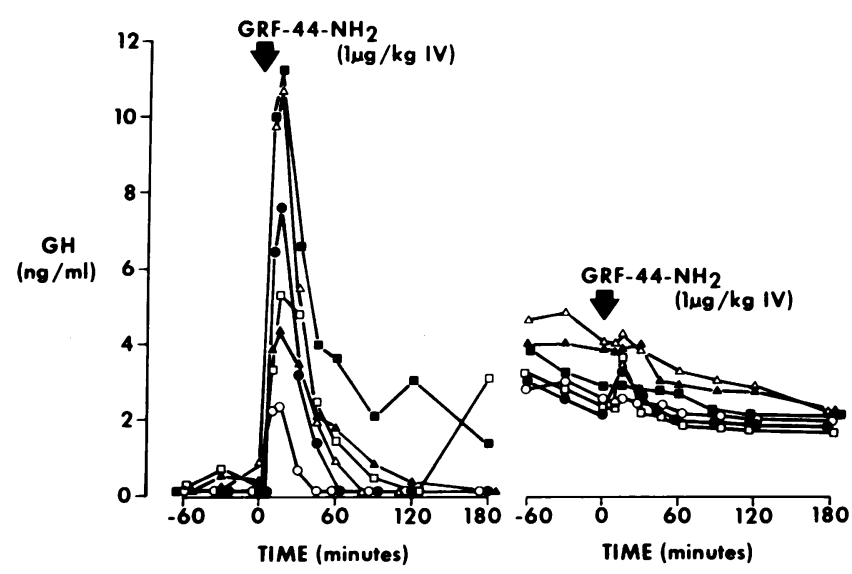

Figure 1. GRF-induced GH response before and after placebo $(A, B)$ and before and after $\mathrm{GH}(C, D)$. Responses in each subject are identified by the same symbol in all four studies. A large variability is noted both within the same subject and between subjects in all studies before GH treatment. The variability between individuals and the incremental rise over time 0 values were markedly diminished after $\mathrm{GH}$ treatment.

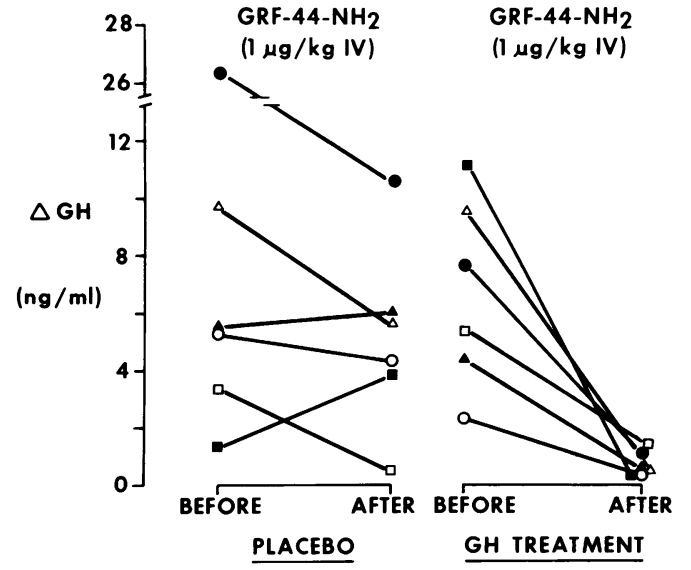

Figure 2. GRF-induced GH response before and after placebo and GH. The responses in Fig. 1 have been expressed as the maximal increment $(\Delta)$ over the time 0 , GRF value. The GH response evoked by GRF was significantly inhibited after GH treatment $(P=0.05)$ but was not significantly affected by placebo.

ject as well. In addition, several subjects demonstrated spontaneous GH pulses before GRF administration (before the first and second bolus injections of GRF, in particular); however, no correlation was noted between the presence of a spontaneous pulse and the subsequent response to GRF.

In Fig. 2, the raw data from Fig. 1 have been expressed as the maximal increment over the time $0, G R F$ value. The incremental $\mathrm{GH}$ response evoked by $\mathrm{GRF}-44-\mathrm{NH}_{2}$ was significantly inhibited after $\mathrm{GH}$ treatment $(0-1.3$ vs. $2.3-11.2 \mathrm{ng} / \mathrm{ml}$ before treatment, $P=0.05$ ), but was not significantly affected by placebo (1.3-26.3 vs. $0.5-10.6 \mathrm{ng} / \mathrm{ml}$ before and after placebo, respectively). In two subjects who underwent GRF stimulation $24 \mathrm{~h}$ after completion of $\mathrm{GH}$ treatment, the plasma $\mathrm{GH}$ response remained impaired (Fig. 3).

The baseline SM-C concentration (time 0, GRF) was significantly increased after $5 \mathrm{~d}$ of $\mathrm{GH}$ treatment (2.66-5.00 vs. $0.92-1.91 \mathrm{U} / \mathrm{ml}$ before treatment, $P=<0.01$ ) as illustrated in Fig. 4. Serum SM-C increased within $24 \mathrm{~h}$ of GH treatment in all subjects (data not shown). In the two subjects who underwent additional GRF stimulation $24 \mathrm{~h}$ after completion of $\mathrm{GH}$ treatment, SM-C concentrations (time 0, GRF) were 4.1 and 4.3 $\mathrm{U} / \mathrm{ml}$.

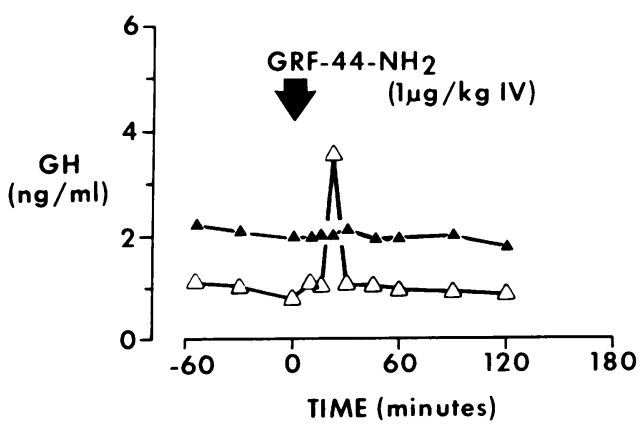

Figure 3. GRF-induced GH response $24 \mathrm{~h}$ after completion of $\mathrm{GH}$ treatment in two subjects. The incremental rise over time 0 values continued to be diminished in comparison with pre-GH treatment studies (see Fig. 1, same symbols). 


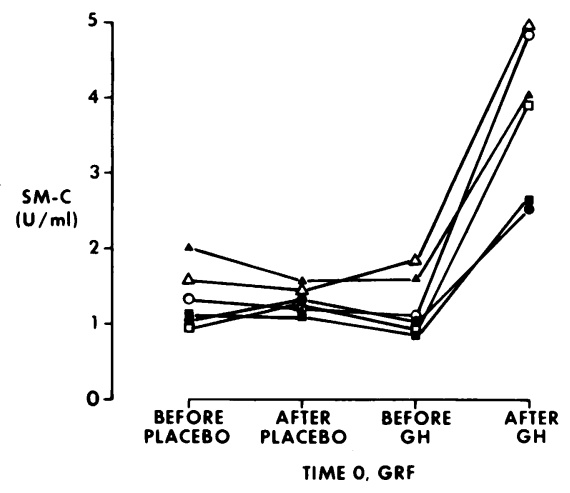

Figure 4. Baseline SM-C concentration before and after placebo and GH. The individual SM-C concentrations (time 0, GRF) are noted for each subject. SM-C concentrations were significantly increased after 5 $\mathrm{d}$ of $\mathrm{GH}$ treatment $(P=<0.01)$.

\section{Discussion}

The results demonstrate that the administration of methionyl human GH inhibits GRF-induced GH secretion in normal men. This impaired pituitary response to GRF may persist for at least $24 \mathrm{~h}$ and is associated with a significant increase in serum SMC concentrations.

In the mid-1960s, it was suggested that one aspect of the regulation of $\mathrm{GH}$ secretion involved an autofeedback mechanism. Studies in the rat, and those which followed in the monkey and human, demonstrated that the administration of $\mathrm{GH}$ led to diminished pituitary $\mathrm{GH}$ content, blunting of the $\mathrm{GH}$ response to provocative stimuli, and decreased pulsatile $\mathrm{GH}$ secretion (112). The implication was that unlike other anterior pituitary hormones, GH did not appear to be influenced by feedback from a peripheral target gland, but regulated its own secretion via a short-loop negative feedback system (1-11).

Subsequent studies have elucidated the complexity of factors involved in the regulation of $\mathrm{GH}$ secretion. The isolation, characterization, and synthesis of somatostatin (13) and GRF (14, 15) firmly established the importance of these two hypothalamic peptides, one inhibitory and the other stimulatory, in the control of GH secretion. Further, it was shown that GH had a direct stimulatory effect on somatostatin release both in vitro (16) and in vivo (17-19). In addition, studies on the interactions of somatostatin and GRF demonstrated that somatostatin noncompetitively blocked GRF-induced GH release in vitro $(20,21)$, and somatostatin antiserum potentiated the GH response to GRF in rats (27) and rabbits (28) in vivo.

Further, the GH-dependent growth factor, SM-C (29), has been shown to mediate $\mathrm{GH}$ negative feedback at both the level of the hypothalamus and the pituitary gland (22-24). At the hypothalamic level, SM-C directly stimulates somatostatin release (22); at the pituitary level, SM-C directly inhibits GH release stimulated by dibutyryl cyclic AMP (22) or by GRF (22-23). These interrelationships are summarized in Fig. 5.

The present in vivo study demonstrates that, in normal men, the $\mathrm{GH}$ response to GRF following $\mathrm{GH}$ administration is blunted in association with significantly elevated somatomedin concentrations. This is in contrast with the variable but often normal GRF-induced GH response in acromegalic patients despite elevated basal concentrations of both $\mathrm{GH}$ and SM-C $(30,31)$.
A

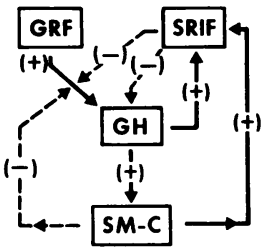

B

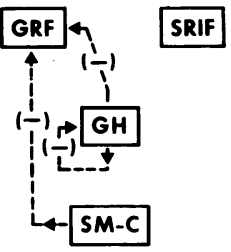

Figure 5. $(A)$ Interrelationships which have been demonstrated between GRF, SRIF, GH, and SM-C. Solid arrows represent stimulation $(+)$ while interrupted arrows represent inhibition $(-) .(B)$ Other potential interrelationships between these peptides, including a direct inhibitory effect of GH on the pituitary somatotropes, and inhibition of hypothalamic GRF secretion by GH and SM-C.

Patients with a GH-secreting pituitary adenoma, however, frequently demonstrate abnormal patterns of $\mathrm{GH}$ secretion to a variety of physiologic and pharmacologic stimuli (e.g., glucose, L-dopa, thyrotropin-releasing factor, and luteinizing hormonereleasing factor).

There are several possible explanations, not mutually exclusive, for this blunted GH response to GRF in normal subjects. The impaired pituitary response could be mediated by: (a) somatomedin, either through stimulation of hypothalamic somatostatin (22) or by inhibition of GH secretion evoked by GRF $(22,23)$, or by both mechanisms; $(b)$ somatostatin stimulated by $\mathrm{GH}$ itself (16-19); or (c) by a direct inhibitory effect of $\mathrm{GH}$ on the pituitary somatotrope. We did not measure peripheral somatostatin in this study as we were unable to demonstrate a change in somatostatin concentrations (unpublished data) during previous dose-response investigations with GRF-44-NH $\mathrm{NH}_{2}$ Other investigators have reported no change in somatostatin concentration following intravenous bolus administration of GRF-40 (32) and no change in thyroid-stimulating hormone or thyrotropin-releasing factor-induced thyroid-stimulating hormone levels during continuous intravenous infusion of GRF-40 (33).

The possible existence of a direct inhibitory effect of $\mathrm{GH}$ on the pituitary somatotropes is not resolved by this study. A pharmacologic dose of $\mathrm{GH}$ was used since we found in a previous study that a comparable dose inhibited the rise in the concentration of plasma $\mathrm{GH}$ elicited by insulin-induced hypoglycemia (9). Despite the pharmacologic dose of $\mathrm{GH}$ in the current study, plasma $\mathrm{GH}$ levels had fallen to the $2-4 \mathrm{ng} / \mathrm{ml}$ range in all patients by $12 \mathrm{~h}$ after the final $\mathrm{GH}$ injection, at which time GRF was given (Fig. 1 D). The low levels of plasma $\mathrm{GH}$ which were measured at the time the impaired pituitary response to GRF was observed do not exclude a direct inhibitory effect of $\mathrm{GH}$ as the biological effect of GH may persist beyond the time of its peak plasma concentration.

A direct inhibitory effect of GH on the somatotropes would presumably require the presence of $\mathrm{GH}$ receptors; to our knowledge, such receptors have not been demonstrated on somatotropes. Laron dwarfism is a growth disorder which may involve an abnormality of the GH receptor at this level. Such patients have end-organ resistance to GH (34) associated with elevated GH concentrations, decreased SM-C concentrations, and lack of a growth response to exogenous GH. One might suggest that the elevated GH concentrations in patients with Laron dwarfism are a consequence of the lack of SM-C feedback. However, their elevated $\mathrm{GH}$ concentrations could be related to a $\mathrm{GH}$ receptor 
abnormality at the hypothalamic-pituitary level, to the low concentration of SM-C, or to both factors. If the concept of GH autofeedback is not limited to a direct pituitary effect of GH on its own secretion, then the results of this study in normal men may be viewed as further evidence for $\mathrm{GH}$ autoregulation. In any event, the present study suggests that after GH treatment, the blunted GH response to synthetic GRF is not solely a consequence of the inhibition of hypothalamic GRF secretion.

An additional aspect of the study is noteworthy. The experimental design provided an opportunity to observe the variability in the GH response evoked by a single GRF bolus in the same subject. As noted, each subject received a bolus injection of the same dose of GRF on three separate occasions before administration of $\mathrm{GH}$. These data emphasize the striking variability in the GRF-induced GH response not only between individuals, as previously reported (35), but within the same individual as well.

The results of this study may have a bearing on the potential usefulness of GRF or an analogue as a treatment for children whose GH deficiency is secondary to deficient secretion of hypothalamic GRF (36-40). As elevated levels of GH are capable of suppressing the GRF-induced GH response, this effect warrants consideration in determining the optimal frequency of GRF (analogue) administration as a growth-promoting agent.

\section{Acknowledgments}

The authors wish to thank Dr. Nicholas Ling and Dr. Roger Guillemin for providing the synthetic GRF-44-NH $\mathrm{N}_{2}$, Genentech, Inc., South San Francisco, CA for contributing the biosynthetic methionyl human GH, and Christine Stav for her secretarial assistance.

This work was supported in part by grants from the U. S. Public Health Service (No. R01 HD02335) and the General Clinical Research Center of the University of California at San Francisco (No. RR00079). Dr. Hulse is a trainee sponsored by the King's Fund and St. Thomas Hospital, London, England.

\section{References}

1. Krulich, L., and S. M. McCann. 1966. Influence of growth hormone (GH) on content of GH in the pituitaries of normal rats. Proc. Soc. Exp. Biol. Med. 121:1114-1117.

2. MacLeod, R. M., M. C. Smith, and G. W. DeWitt. 1966. Hormonal properties of transplanted pituitary tumors and their relation to the pituitary gland. Endocrinology. 79:1149-1156.

3. MacLeod, R. M., G. W. DeWitt, and M. C. Smith. 1968. Suppression of pituitary gland hormone content by pituitary tumor hormones. Endocrinology. 82:889-894.

4. Peake, G. T., I. K. Mariz, and W. H. Daughaday. 1968. Radioimmunoassay of growth hormone in rats bearing somatotropin producing tumors. Endocrinology. 83:714-720.

5. Katz, S. H., M. Molitch, and S. M. McCann. 1969. Effect of hypothalamic implants of GH on anterior pituitary weight and GH concentration. Endocrinology. 85:725-734.

6. Voogt, J. L., J. A. Clemens, A. Negro-Vilar, C. Welsch, and J. Meites. 1971. Pituitary GH and hypothalamic GHRF after median eminence implantation of ovine or human GH. Endocrinology. 88:13631367.

7. Müller, E., and A. Pecile. 1966. Influence of exogenous growth hormone on endogenous growth hormone release. Proc. Soc. Exp. Biol. Med. 122:1289-1291.

8. Sakuma, M., and E. Knobil. 1970. Inhibition of endogenous growth hormone secretion by exogenous growth hormone infusion in the rhesus monkey. Endocrinology. 86:890-894.
9. Abrams, R. L., M. M. Grumbach, and S. L. Kaplan. 1971. The effect of administration of human growth hormone on the plasma growth hormone, cortisol, glucose, and free fatty acid response to insulin. Evidence for growth hormone autoregulation in man. J. Clin. Invest. 50: 940-950.

10. Hagen, T. C., A. M. Lawrence, and L. Kirsteins. 1972. Autoregulation of growth hormone secretion in normal subjects. Metab. Clin. Exp. 21:603-610.

11. Tannenbaum, G. S. 1980. Evidence for autoregulation of growth hormone secretion via the central nervous system. Endocrinology. 107: 2117-2120.

12. Mendelson, W. B., L. S. Jacobs, and J. C. Gillin. 1983. Negative feedback suppression of sleep-related growth hormone secretion. J. Clin. Endocrinol. Metab. 56:486-488.

13. Brazeau, P., W. Vale, R. Burgus, N. Ling, M. Butcher, J. Rivier, and R. Guillemin. 1973. Hypothalamic polypeptide that inhibits the secretion of immunoreactive pituitary growth hormone. Science (Wash. DC). 179:77-79.

14. Guillemin, R., P. Brazeau, P. Böhlen, F. Esch, N. Ling, and W. B. Wehrenberg. 1982. Growth hormone-releasing factor from a human pancreatic tumor that caused acromegaly. Science (Wash. DC). 218:585-587.

15. Rivier, J., J. Spiess, M. Thorner, and W. Vale. 1982. Characterization of a growth hormone-releasing factor from a human pancreatic islet tumour. Nature (Lond.). 300:276-278.

16. Sheppard, M. C., S. Kronheim, and B. L. Pimstone. 1978. Stimulation by growth hormone of somatostatin release from the rat hypothalamus in vitro. Clin. Endocrinol. 9:583-586.

17. Patel, Y. C. 1979. Growth hormone stimulates hypothalamic somatostatin. Life Sci. 24:1589-1593.

18. Berelowitz, M., S. L. Firestone, and L. A. Frohman. 1981. Effects of growth hormone excess and deficiency on hypothalamic somatostatin content and release and on tissue somatostatin distribution. Endocrinology. 109:714-719.

19. Chihara, K., N. Minamitani, H. Kaji, A. Arimura, and T. Fujita. 1981. Intraventricularly injected growth hormone stimulates somatostatin release into rat hypophyseal portal blood. Endocrinology. 109:2279-2281.

20. Brazeau, P., N. Ling, P. Böhlen, F. Esch, S-Y. Ying, and R. Guillemin. 1982. Growth hormone releasing factor, somatocrinin, releases pituitary growth hormone in vitro. Proc. Natl. Acad. Sci. USA. 79:79097913.

21. Vale, W., J. Vaughan, G. Yamamoto, J. Spiess, and J. Rivier. 1983. Effects of synthetic human pancreatic (tumor) $\mathrm{GH}$ releasing factor and somatostatin, triiodothyronine and dexamethasone on $\mathrm{GH}$ secretion in vitro. Endocrinology. 112:1553-1555.

22. Berelowitz, M., M. Szabo, L. A. Frohman, S. Firestone, L. Chu, and R. L. Hintz. 1981. Somatomedin-C mediates growth hormone negative feedback by effects on both the hypothalamus and the pituitary. Science (Wash. DC). 212:1279-1281.

23. Brazeau, P., R. Guillemin, N. Ling, J. Van Wyk, and R. Humbel. 1982. Inhibition par les somatomédines de la sécrétion de l'hormone de croissance stimulée par le facteur hypothalamique somatocrinine (GRF) ou le peptide de synthèse hpGRF. C.R. Acad. Sc. Paris (III). 295:651654.

24. Tannenbaum, G. S., H. J. Guyda, and B. I. Posner. 1983. Insulinlike growth factors: a role in growth hormone negative feedback and body weight regulation via brain. Science (Wash. DC). 220:77-79.

25. Youlton, R., S. L. Kaplan, and M. M. Grumbach. 1969. Growth and growth hormone. IV. Limitations of the growth hormone response to insulin and arginine and of the immunoreactive insulin response to arginine in the assessment of growth hormone deficiency in children. Pediatrics. 43:989-1004.

26. Van Vliet, G., D. M. Styne, S. L. Kaplan, and M. M. Grumbach. 1983. Growth hormone treatment for short stature. N. Engl. J. Med. 309:1016-1022.

27. Wehrenberg, W. B., N. Ling, P. Böhlen, F. Esch, P. Brazeau, and R. Guillemin. 1982. Physiological roles of somatocrinin and somatostatin 
in the regulation of growth hormone secretion. Biochem. Biophys. Res. Commun. 109:562-567.

28. Chihara, K., N. Minamitani, H. Kaji, H. Kodama, T. Kita, and T. Fujita. 1983. Human pancreatic growth hormone-releasing factor stimulates release of growth hormone in conscious unrestrained male rabbits. Endocrinology. 113:2081-2085.

29. Phillips, L. S., and R. Vassilopoulou-Sellin. 1980. Somatomedins. N. Engl. J. Med. 302:371-380, 438-446.

30. Shibasaki, T., K. Shizume, A. Masuda, M. Nakahara, N. Hizuka, M. Miyakawa, K. Takano, H. Demura, I. Wakabayashi, and N. Ling. 1984. Plasma growth hormone response to growth hormone-releasing factor in acromegalic patients. J. Clin. Endocrinol. Metab. 58:215-217.

31. Gelato, M. C., G. R. Merriam, M. L. Vance, J. A. Goldman, C. Webb, W. S. Evans, J. Rock, H. H. Oldfield, M. E. Molitch, J. Rivier, W. Vale, S. Reichlin, L. A. Frohman, D. L. Loriaux, and M. O. Thorner. 1985. Effects of growth hormone-releasing factor on growth hormone secretion in acromegaly. J. Clin. Endocrinol. Metab. 60:251-257.

32. Thorner, M. O., J. Spiess, M. L. Vance, A. D. Rogol, D. L. Kaiser, J. D. Webster, J. Rivier, J. L. Borges, S. R. Bloom, M. J. Cronin, W. S. Evans, R. M. MacLeod, and W. Vale. 1983. Human pancreatic growth-hormone-releasing factor selectively stimulates growth-hormone secretion in men. Lancet. i:24-28.

33. Webb, C. B., M. L. Vance, M. O. Thorner, G. Perisutti, J. Thominet, J. Rivier, W. Vale, and L. A. Frohman. 1984. Plasma growth hormone responses to constant infusions of human pancreatic growth hormone releasing factor. J. Clin. Invest. 74:96-103.

34. Jacobs, L. S., D. S. Sneid, J. T. Garland, Z. Laron, and W. Daughaday. 1976. Receptor-active growth hormone in Laron dwarfism. J. Clin. Endocrinol. Metab. 42:403-406.
35. Rosenthal, S. M., E. A. Schriock, S. L. Kaplan, R. Guillemin, and M. M. Grumbach. 1983. Synthetic human pancreas growth hormonereleasing factor $\left(\mathrm{hpGRF}_{1-44}-\mathrm{NH}_{2}\right)$ stimulates growth hormone secretion in normal men. J. Clin. Endocrinol. Metab. 57:677-679.

36. Schriock, E. A., R. H. Lustig, S. M. Rosenthal, S. L. Kaplan, and M. M. Grumbach. 1984. Effect of growth hormone (GH)-releasing hormone (GRH) on plasma $\mathrm{GH}$ in relation to magnitude and duration of GH deficiency in 26 children and adults with isolated GH deficiency or multiple pituitary hormone deficiencies: evidence for hypothalamic GRH deficiency. J. Clin. Endocrinol. Metab. 58:1043-1049.

37. Sassolas, G., H. Rousset, R. Cohen, P. Chatelain, B. Claustrat, S. Laporte, B. Laferrère, A. El Charfi, and S. Ferry. 1983. La somatocrinine provoque la libération de somathormone dans un cas de déficit en somathormone d'origine hypothalamique chez l'enfant. C.R. Acad. Sc. Paris (III). 296:527-530.

38. Borges, J. L. C., R. M. Blizzard, M. C. Gelato, R. Furlanetto, A. D. Rogol, W. S. Evans, M. L. Vance, D. L. Kaiser, R. M. MacLeod, G. R. Merriam, D. L. Loriaux, J. Spiess, J. Rivier, W. Vale, and M. O. Thorner. 1983. Effects of human pancreatic tumour growth hormone releasing factor on growth hormone and somatomedin $\mathrm{C}$ levels in patients with idiopathic growth hormone deficiency. Lancet. ii:119-124.

39. Grossman, A., M. O. Savage, J. A. H. Wass, N. Lytras, J. SueirasDiaz, D. H. Coy., and G. M. Besser. 1983. Growth-hormone-releasing factor in growth hormone deficiency: demonstration of a hypothalamic defect in growth hormone release. Lancet. ii:137-138.

40. Takano, K., N. Hizuka, K. Shizume, K. Asakawa, M. Miyakawa, N. Hirose, T. Shibasaki, and N. C. Ling. 1984. Plasma growth hormone (GH) response to GH-releasing factor in normal children with short stature and patients with pituitary dwarfism. J. Clin. Endocrinol. Metab. $58: 236-241$. 